\title{
Erosion of Magnesium Potassium Phosphate Ceramic Waste Forms*
}

K. C. Goretta, D. Singh, M. Tlustochowicz, M. M. Cuber, M. L. Burdt, S. Y. Jeong, T. L. Smith, A. S. Wagh, and J. L. Routbort

Energy Technology Division Argonne National Laboratory, Argonne, IL 60439-4838

November 1998

The submitted manuscript has been created by the University of Chicago as Operator of Argonne National Laboratory ("Argonne") under Contract No. W-31-109-ENG-38 with the U.S. Department of Energy. The U.S. Government retains for itself, and othors acting on it bebalf, a paid-up, nonexclusive, irrevocable worldwide license in said article to reproduce, prepare derivative works, distribute copies to the public, and perform publiely and display publicly, by or on behalf of the Government.

Submitted to Proceedings of 1998 Fall Meeting of the Materials Research Society, Boston, MA, Nov. 30-Dec. 4, 1998.

*Work supported by the U.S. Department of Energy (DOE), Office of Science and Technology, as part of the Mixed Waste Focus Area, and the Argonne Division of Educational Programs with funding from DOE, under Contract W-31-109-Eng-38. 


\section{DISCLAIMER}

This report was prepared as an account of work sponsored by an agency of the United States Government. Neither the United States Government nor any agency thereof, nor any of their employees, make any warranty, express or implied, or assumes any legal liability or responsibility for the accuracy, completeness, or usefulness of any information, apparatus, product, or process disclosed, or represents that its use would not infringe privately owned rights. Reference herein to any specific commercial product, process, or service by trade name, trademark, manufacturer, or otherwise does not necessarily constitute or imply its endorsement, recommendation, or favoring by the United States Government or any agency thereof. The views and opinions of authors expressed herein do not necessarily state or reflect those of the United States Government or any agency thereof. 


\section{DISCLAIMER}

Portions of this document may be illegible in electronic image products. Images are produced from the best available original document. 


\title{
EROSION OF MAGNESIUM POTASSIUM PHOSPHATE CERAMIC WASTE FORMS
}

K. C. GORETTA, D. SINGH, M. TLUSTOCHOWICZ, M. M. CUBER, M. L. BURDT, S. Y. JEONG, T. L. SMITH, A. S. WAGH, J. L. ROUTBORT

Energy Technology Division, Argonne National Laboratory, Argonne, IL 60439-4838

\begin{abstract}
Phosphate-based chemically bonded ceramics were formed from magnesium potassium phosphate (MKP) binder and either industrial fly ash or steel slag. The resulting ceramics were subjected to solid-particle erosion by a stream of either angular $\mathrm{Al}_{2} \mathrm{O}_{3}$ particles or rounded $\mathrm{SiO}_{2}$ sand. Particle impact angles were 30 or $90^{\circ}$ and the impact velocity was $50 \mathrm{~m} / \mathrm{s}$. Steady-state erosion rates, measured as mass lost from a specimen per mass of impacting particle, were dependent on impact angle and on erodent particle size and shape. Material was lost by a combination of fracture mechanisms. Evolution of $\mathrm{H}_{2} \mathrm{O}$ from the MKP phase appeared to contribute significantly to the material loss.
\end{abstract}

\section{INTRODUCTION}

Phosphate-based chemically bonded ceramics are being used to stabilize many types of industrial or nuclear wastes. Many of the industrial wastes consist of nonhazardous fly ash, which can be used in value-added products. For example, approximately one-third of the ash produced by utilities is recycled as an additive to cements [1]. Phosphate-based cements have advantages over Portland cements because they can incorporate substantially higher ash loadings and can form strong products from ash having wide ranges of chemical compositions [2-6].

We have developed a novel chemically bonded phosphate ceramic called Ceramicrete. Final ash-containing Ceramicrete products exhibit high strength and little open porosity. They are therefore suitable for many potential applications [2-6].

We have examined the resistance of Ceramicrete to solid-particle erosion because Ceramicrete products may find use in hostile environments and because of specific interest in grit erosion of cement and concrete. Decontamination of large buildings once used for reprocessing spent nuclear fuel at the Hanford site in Washington and the Savannah River Site in South Carolina will require removal of radioactive contaminants from structures before decommissioning and possible demolition $[7,8]$. Because of high radiation levels, decontamination will require use of remote or robotic technology, probably based on abrasive erosion provided by grit blasting. Such decontamination techniques must be well understood in order to predict the efficiency and costs of decontamination. Despite this technological interest in the solid-particle erosion of cement and concrete, relatively little effort has been devoted to its study [8]. Although a wealth of data is available on solid-particle erosion of engineering materials [9-11], and several models exhibit success in predicting response to erosive conditions [12-14], little is known about the response of Ceramicrete or other cement-based materials.

\section{EXPERIMENTS}

\section{Specimen Fabrication}

Ceramicrete synthesis is based on an acid-base reaction between $\mathrm{MgO}$ and a solution of alkali phosphate salts, such as sodium or potassium phosphate. Our specimens were formed by the reaction

$$
\mathrm{MgO}+\mathrm{KH}_{2} \mathrm{PO}_{4}+5 \mathrm{H}_{2} \mathrm{O} \rightarrow \mathrm{MgKPO}_{4} \cdot 6 \mathrm{H}_{2} \mathrm{O} .
$$


This product is the binder (referred to as MKP) that constitutes the cement matrix [2-6]. Resultant composite products, which can incorporate ash, slag, low-level nuclear wastes, or other hazardous inorganic or organic materials, have been subjected to tests of stability in aqueous media [15,16] and found to be highly resistant to leaching [2-6].

For these studies, we fabricated 2-cm-diameter MKP-based test samples that incorporated 50 or $60 \mathrm{wt} . \%$ Class $\mathrm{C}$ or Class $\mathrm{F}$ fly ash, or $65 \mathrm{wt} . \%$ steel-mill slag. The samples were cured for $\approx 1$ month, and then specimens for erosion testing were cut with a diamond-blade band saw. A few of the specimens were polished to a $1-\mu \mathrm{m}$ finish so that the surfaces could be examined by $\mathrm{X}$-ray diffraction (XRD) and scanning electron microscopy (SEM).

The ash-containing specimens exhibited average densities of $\approx 1.6-1.9 \mathrm{~g} / \mathrm{cm}^{3}$ and porosities $<20 \%$. The slag-containing specimens exhibited average densities of $\approx 2.6 \mathrm{~g} / \mathrm{cm}^{3}$ and porosities $<20 \%$.

\section{Erosion Tests}

The erosion tests were conducted at room temperature in a slinger-type apparatus that was evacuated to a pressure of $\approx 50 \mathrm{~Pa}[7,17,18]$. The erodents were angular $\mathrm{Al}_{2} \mathrm{O}_{3}$ (Norton Alundum 38) with average particle size, $\mathrm{D}$, of 42 or $390 \mu \mathrm{m}$; or $\mathrm{SiO}_{2}$ sand with an average diameter of $\approx 450 \mu \mathrm{m}$. The erodent velocity, $V$, was $50 \mathrm{~m} / \mathrm{s}$, and the angles of impact, $\alpha$, were 30 and $90^{\circ}$.

Specimens were weighed to the nearest $0.1 \mathrm{mg}$, subjected to erosion by one of the erodents, cleaned by brushing, and then reweighed. Steady-state erosion was determined as the mass lost from the target per mass of impacting particles. At least four test cycles were conducted to define the steady-state erosion rate, $\Delta \mathrm{M}$. Steady-state surfaces were then examined by SEM. In addition, polished specimens were impacted by only a few erodent particles so that individual impact sites could also be examined.

\section{Property Characterization}

It has been shown that impact by high-velocity solid particles can produce local melting in low-ductility metals [18] and ceramics [19]. We therefore examined the thermal stability of our MKP-based specimens. Differential thermal analysis (DTA) and thermogravimetric analysis (TGA) were used to determine the temperature range over which $\mathrm{H}_{2} \mathrm{O}$ is lost from MKP and whether other phase transformations occur at elevated temperatures.

Specimens were also prepared for measurement of crushing strength. The compressive surfaces were ground to be flat and parallel. To examine the effects of heating, sets of four Ceramicrete specimens that contained $50 \mathrm{wt} . \%$ Class $\mathrm{F}$ fly ash were heated in air to temperatures of $225,500,750$, and $1000^{\circ} \mathrm{C}$. The heating schedule consisted of $10^{\circ} \mathrm{C} / \mathrm{h}$ to $120^{\circ} \mathrm{C}$, then $120^{\circ} \mathrm{C} / \mathrm{h}$ to the maximum temperature, holding at that temperature for $2-30 \mathrm{~h}$, and then cooling to room temperature at $\approx 120^{\circ} \mathrm{C} / \mathrm{h}$. Final densities were calculated from mass and dimension measurements. For the crushing-strength tests, specimens were placed between cardboard sheets and compressed at a rate of $0.2 \mathrm{~mm} / \mathrm{s}$.

\section{RESULTS AND DISCUSSION}

XRD indicated that all specimens consisted primarily of the crystalline MKP, unreacted $\mathrm{MgO}$, and traces of the ash or slag additives. The residual $\mathrm{MgO}$ resulted because some cations from the fly ash or slag became incorporated in the MKP phase. The formulations were based on stoichiometric incorporation of $\mathrm{Mg}$, and thus excess $\mathrm{MgO}$ remained. SEM revealed a complex microstructure that consisted of a very fine-grained matrix, porosity, and generally coarse silicate-based phases (Fig. 1). The silicate phases are the remnants of the ash or slag additives. This microstructure is different from those of most engineering materials, but is typical of a cement. 


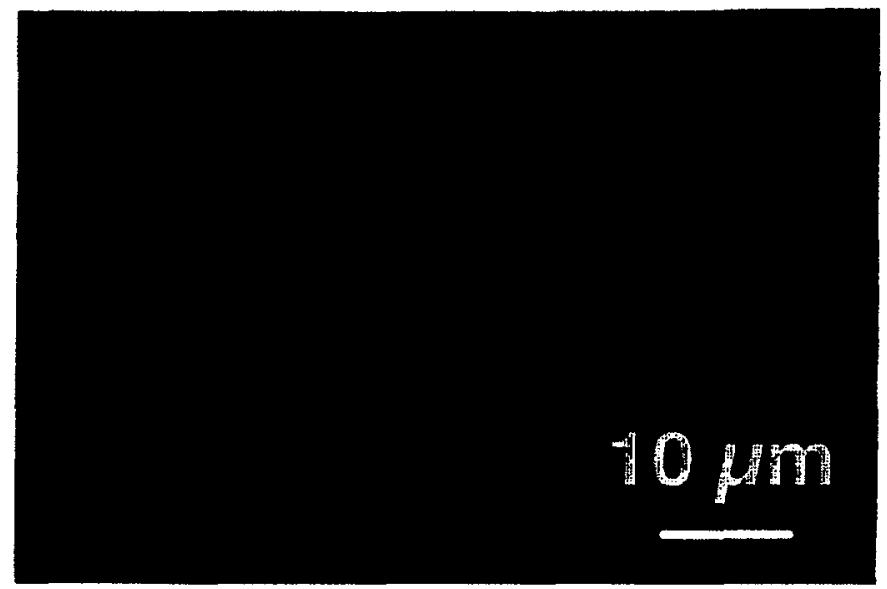

Fig. 1. SEM photomicrograph of $50 \mathrm{wt} \%$ fly ash Ceramicrete specimen.

This material is representative of all specimens. A relatively dense MKP matrix surrounds spherical silicate regions and small pores.

Typical raw data for mass loss per mass of erodent passing through the slinger are shown in Fig. 2. Although the data exhibit some scatter, they can be fitted reasonably well to a straight line. To calculate erosion rates, the data were corrected by a dose factor because only a fraction of the erodent that enters the test chamber actually strikes an individual specimen; the dose factor for $90^{\circ}$ impact is twice that for $30^{\circ}$ impact. $\Delta \mathrm{M}$ is defined as the slope of a plot of specimen mass loss per mass of erodent striking the specimen surface.

$\Delta \mathrm{M}$ data as a function of impact angle for the various Ceramicrete specimens eroded by $42-\mu \mathrm{m} \mathrm{Al}_{2} \mathrm{O}_{3}$ particles are shown in Fig. 3. Values were higher for $\alpha=30^{\circ}$ impact than for $\alpha=$ $90^{\circ}$. The additive type and composition did not have a strong effect on erosion rate. The Class C fly ash samples were slightly more resistant to erosion than were the other materials. In general, because of higher $\mathrm{Ca}$ and lower $\mathrm{C}$ contents, Ceramicrete synthesized from Class $\mathrm{C}$ fly ash tends to be stronger than that synthesized from Class $\mathrm{F}$ fly ash or slag [20]. With impact by larger particles, the trend of $\Delta \mathrm{M}$ versus $\alpha$ was reversed; maximum $\Delta \mathrm{M}$ values were obtained at $90^{\circ}$.

Most metals, for which the dominant mechanism of material removal is some sort of ductile plowing, exhibit maximal erosion rates with impact at $\approx 20-30^{\circ}[21]$. Most ceramics and brittle polymers, for which the dominant mechanism of material removal is formation of lateral cracks at elastic-plastic damage zones, exhibit maximal erosion rates with impact at $90^{\circ}$ [8-14]. All of the Ceramicrete specimens were completely brittle, but when impacted by $42-\mu \mathrm{m} \mathrm{Al}_{2} \mathrm{O}_{3}$ particles, their response to erosion was characteristic of a material that exhibits some ductility. We can offer no credible explanation for the angular dependence of the erosion rate, but note that under some conditions, Portland cement also exhibits the same effect of $\Delta M$ versus angle [8].

As shown in Table I, the erosion rates for Ceramicrete are relatively high with respect to typical engineering materials, but are generally lower than those of Portland-based cement and concrete. Given the density and inherent strength of Ceramicrete, its erosion resistance is about as might be expected. For example, structural ceramics generally exhibit crushing strengths of $\approx 2-6 \mathrm{GPa}$ [24], whereas that of Ceramicrete is generally $<100 \mathrm{MPa}$ [20]. Ceramicrete is strong by the standards of cements, not by those of structural ceramics. However, given the large differences in erosion rates, one might assume that the erosion mechanisms are different for Ceramicrete than for other materials. SEM was used to examine this supposition more closely.

SEM examinations of steady-state fracture surfaces suggested that the material-removal mechanisms were common to all specimens. Surfaces were rough and covered by debris (Fig. 4). The scale of the fractures correlated well with that of the microstructure shown in Fig. 1. 


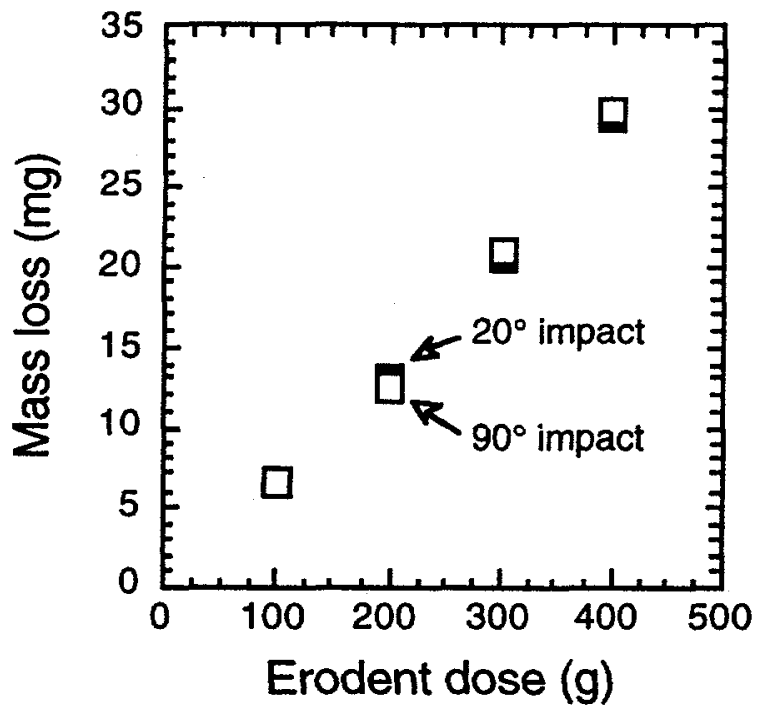

Fig. 2. Representative data for mass loss from $65 \mathrm{wt} \%$ steel slag specimens per dose of $42-\mu \mathrm{m} \mathrm{Al} \mathrm{O}_{3}$ erodent.

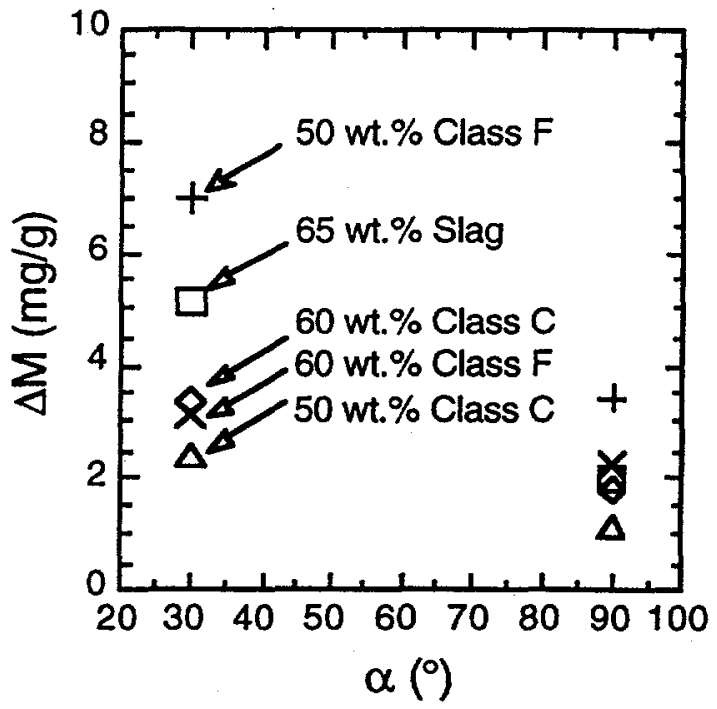

Fig. 3. Erosion rate vs. $\alpha$ for $42-\mu \mathrm{m}$ $\mathrm{Al}_{2} \mathrm{O}_{3}$ erodents impacting Ceramicrete specimens at $50 \mathrm{~m} / \mathrm{s}$.

Individual impact sites generally contained many small fractures, most of which appeared to be intergranular. In general, the material removed per impact was substantial, and little embedding of erodent was observed. There was little difference in appearance between damage from impact at $30^{\circ}$ and at $90^{\circ}$ (Fig. 5). Given the extent of penetration of each erodent particle, it appears that nearly complete transfer of kinetic energy to the target occurred at both angles of impact.

Material removal was a consequence of propagation of large and small fractures. In moreconventional brittle material, impact creates an elastic-plastic zone beneath the impact site. A few radial and lateral cracks emanate from this zone. Furthermore, some of the kinetic energy of

Table I. Erosion rates for various engineering materials impacted by $42-\mu \mathrm{m}$ angular $\mathrm{Al}_{2} \mathrm{O}_{3}$ particles at $\mathrm{V}=50 \mathrm{~m} / \mathrm{s}$.

\begin{tabular}{lccc}
\hline \multicolumn{1}{c}{ Material } & $\Delta \mathrm{M}, \alpha \approx 30^{\circ}(\mathrm{mg} / \mathrm{g})$ & $\Delta \mathrm{M}, \alpha=90^{\circ}(\mathrm{mg} / \mathrm{g})$ & Reference \\
\hline MKP ceramics & $2.3-7.0$ & $1.1-3.4$ & This work \\
Portland cement & 19 & 5 & {$[8]$} \\
Portland concrete & 5 & 2.5 & {$[8]$} \\
Nuclear-waste glass & 0.36 & 0.67 & {$[8]$} \\
Amorphous NiP & - & 0.3 & {$[18]$} \\
Bismaleimide & - & 0.1 & {$[22]$} \\
$2014 \mathrm{Al}, \mathrm{T} 6$ & 0.06 & 0.04 & {$[23]$} \\
$2014 \mathrm{Al}+20 \% \mathrm{SiC}$ & 0.08 & 0.06 & {$[23]$} \\
$\mathrm{SiC}$ & - & 0.045 & {$[23]$} \\
\hline
\end{tabular}



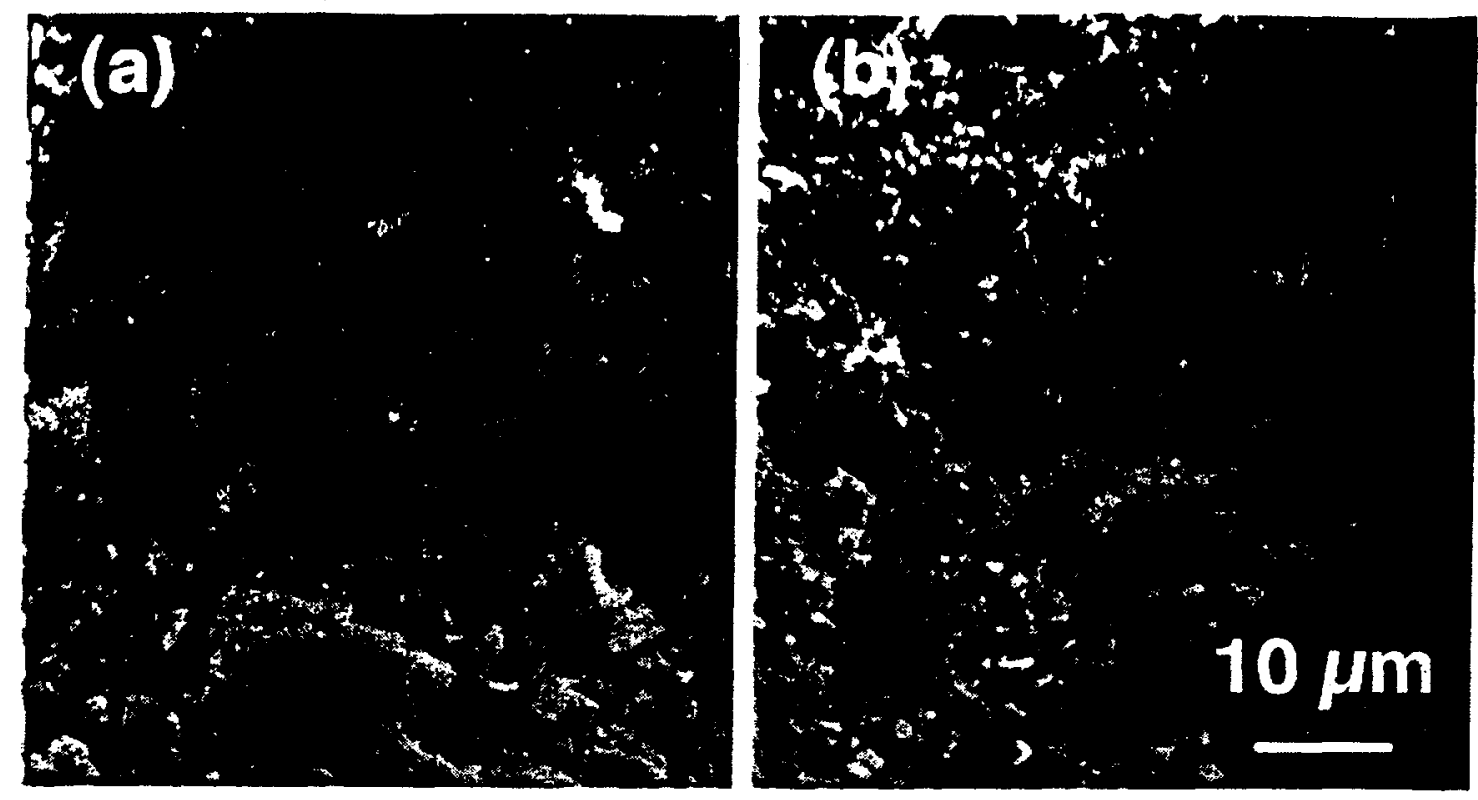

Fig. 4. SEM photomicrographs of eroded Ceramicrete specimens containing $50 \mathrm{wt} . \%$ Class F fly ash: (a) $\alpha=30^{\circ}$ and (b) $\alpha=90^{\circ} ; \mathrm{V}=50 \mathrm{~m} / \mathrm{s}$, erodent $=42 \mu \mathrm{m} \mathrm{Al}_{2} \mathrm{O}_{3}$.
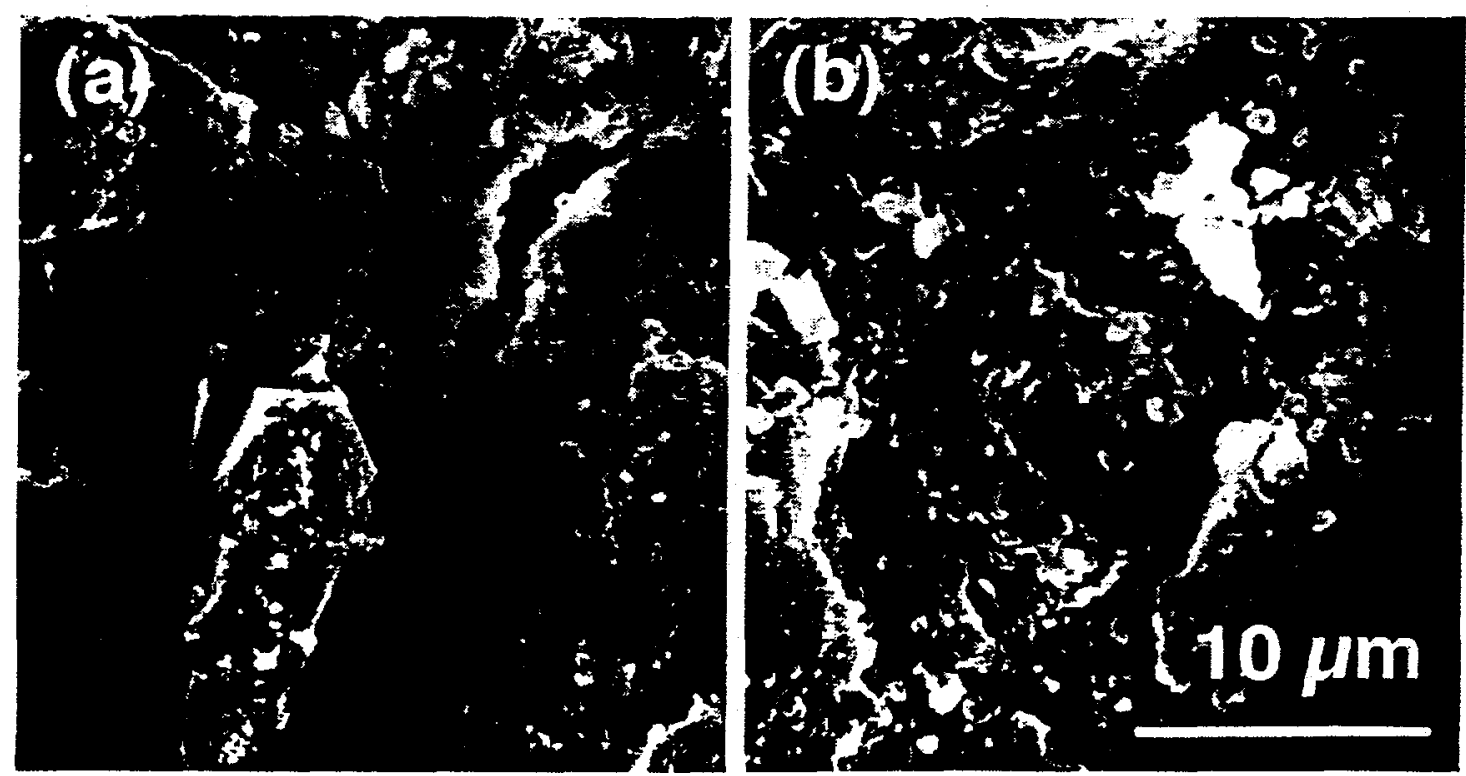

Fig. 5. SEM photomicrographs of individual impact sites of $65 \mathrm{wt} \%$ steel slag Ceramicrete samples eroded by $42-\mu \mathrm{m} \mathrm{Al}_{2} \mathrm{O}_{3}$ : (a) $\alpha=30^{\circ}$ and (b) $\alpha=90^{\circ}$.

an impact is spent as the erodent particle rebounds. Ceramicrete has a relatively low elastic modulus [20] and there was little evidence of lateral cracks propagating from an elastic-plastic zone or of erodent rebound.

In Portland ecment and concrete, many small fractures have also been observed at impact sites [81. These fratures were attributed to a creep phenomenon catused by loss of $\mathrm{H}_{2} \mathrm{O}$, and 
hence destruction of the basic crystal structure of the matrix, because of heating induced by particle impact. As shown in Fig. 6, Ceramicrete loses $\mathrm{H}_{2} \mathrm{O}$ from the hydrated MKP crystals at $\approx 100^{\circ} \mathrm{C}$. Crushing strength and density decrease substantially with this loss (Fig. 7). Except for this $\mathrm{H}_{2} \mathrm{O}$ loss, the phosphate-based binder phase exhibits no other phase transformations to $1400^{\circ} \mathrm{C}[20]$.

If $\mathrm{H}_{2} \mathrm{O}$ loss is indeed integral to erosion of Ceramicrete, we might expect that erosion rates would be higher from impact by angular $\mathrm{Al}_{2} \mathrm{O}_{3}$ particles than by rounded $\mathrm{SiO}_{2}$ sand. The kinetic energy from the sand should be absorbed over a much large area because of its shape, and the maximum temperature at an impact site should therefore be lower. As shown in Fig. 8, $\Delta \mathrm{M}$ values were in fact significantly lower when the rounded erodent was used, especially with impacts at $90^{\circ}$.

With respect to applications, it has also been shown that after exposure to elevated temperatures, Ceramicrete remains highly resistant to chemical leaching $[20,25]$. Thus, although its strength is reduced by elevated temperatures, Ceramicrete retains its ability to stabilize wastes.

Both Ceramicrete and Portland-based cements [8] erode rather quickly. From the standpoint of nuclear-facility decontamination procedures, this property is probably advantageous. For maximum efficiency of material removal, our studies suggest that angular erodents should be used. The erosion studies to date leave, however, many questions unanswered [8]. More work is required before cement erosion can be modeled effectively. In particular, the range of experimental conditions should be broadened to include a wider range of particle size and impact velocity.

\section{CONCLUSIONS}

Ceramicrete that contained 50 or $60 \mathrm{wt} . \%$ industrial Class $\mathrm{C}$ or $\mathrm{F}$ fly ash, or $65 \mathrm{wt} . \%$ steel slag, was subjected to solid-particle erosion by a stream of angular $\mathrm{Al}_{2} \mathrm{O}_{3}$ particles or rounded $\mathrm{SiO}_{2}$ sand. The impact velocity was $50 \mathrm{~m} / \mathrm{s}$ and the impact angle was 30 or $90^{\circ}$. The materialloss mechanism was dominated by formation of large and small fractures at each impact site. Fracturing appeared to have been caused by a combination of direct impact damage and creep from local loss of $\mathrm{H}_{2} \mathrm{O}$, with concomitant reduction is strength, induced by local heating.
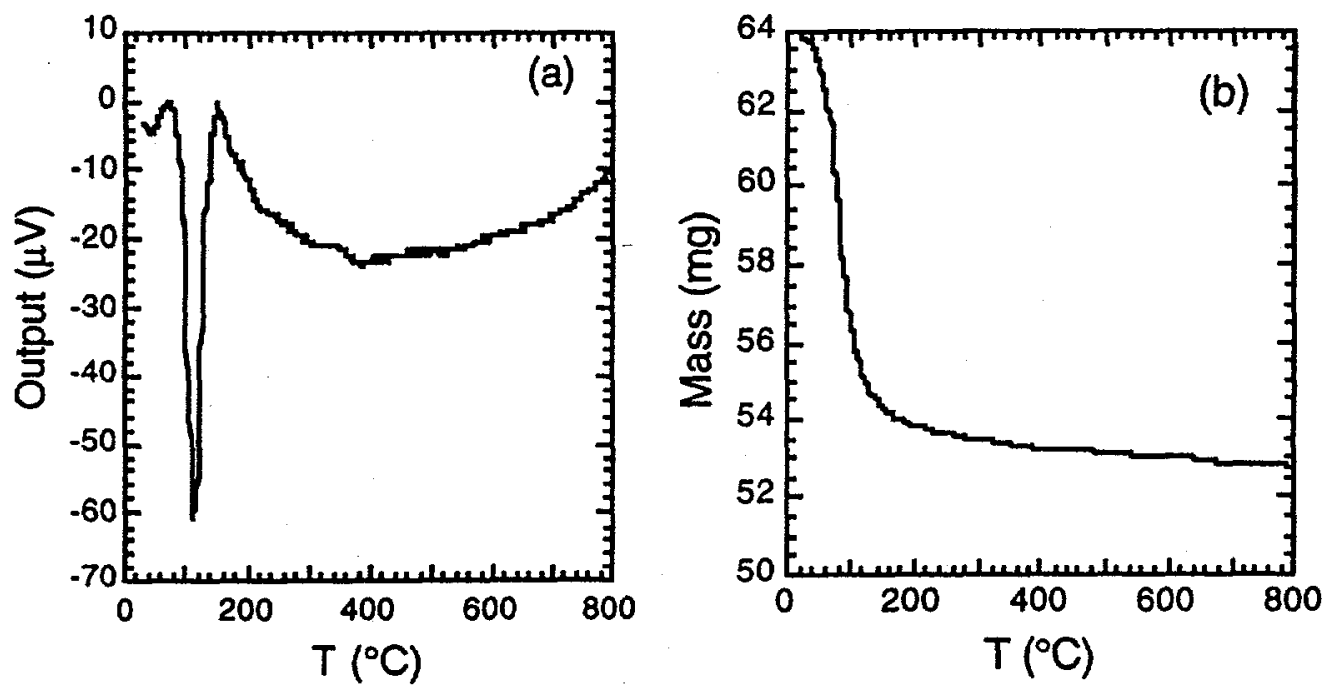

Fig. 6. Ceramicrete specimens containing $50 \mathrm{wt} . \%$ Class $\mathrm{F}$ fly ash heated in air at $300^{\circ} \mathrm{C} / \mathrm{h}$ : (a) DTA and (b) TGA plots. 


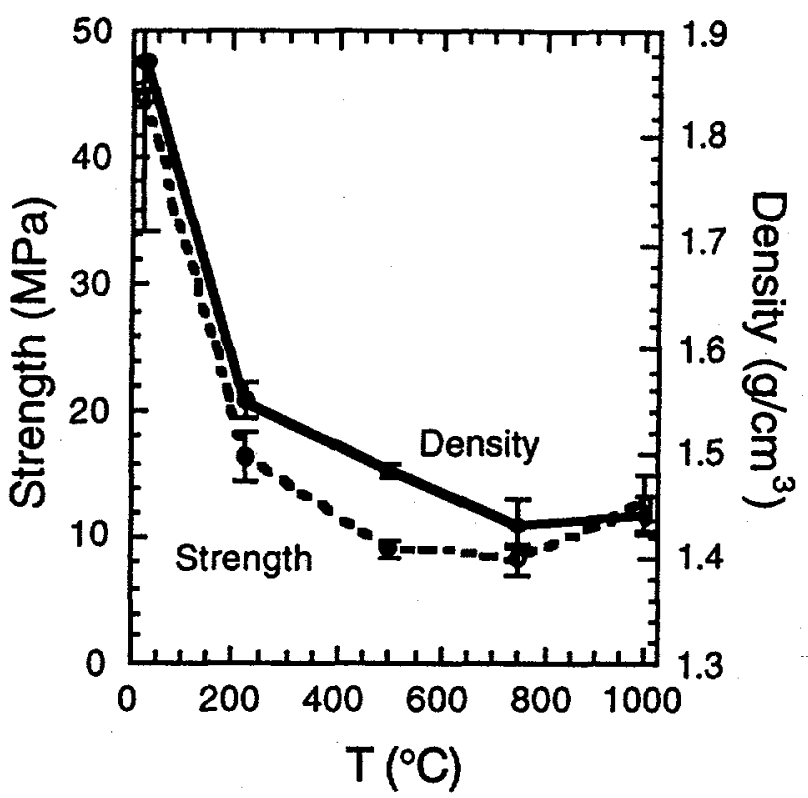

Fig. 7. Crushing strength and density of Ceramicrete containing $50 \mathrm{wt} . \%$ Class $\mathrm{F}$ fly ash vs. exposure at temperature for $2 \mathrm{~h}$.

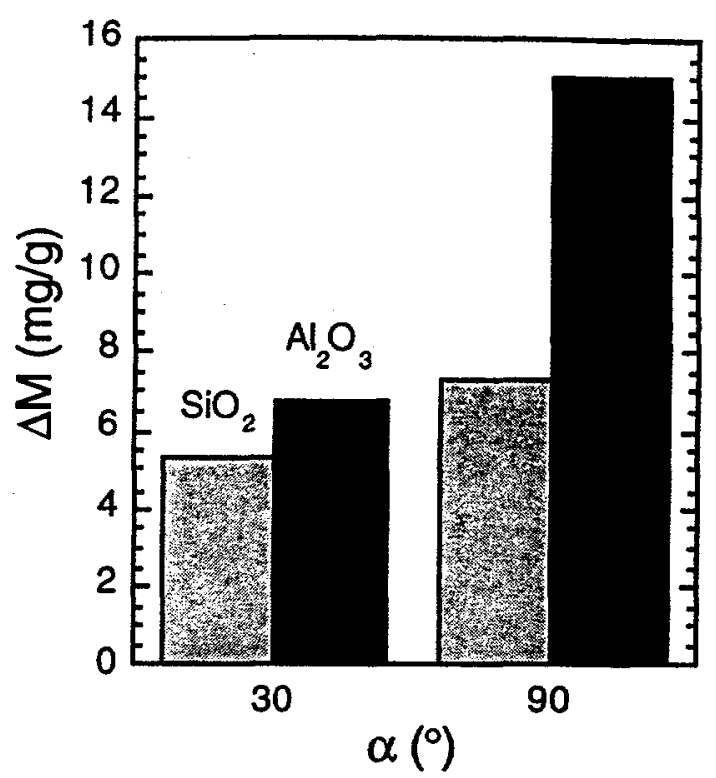

Fig. 8. $\Delta \mathrm{M}$ values for Ceramicrete containing $60 \mathrm{wt} . \%$ Class F fly ash; $\mathrm{V}=50 \mathrm{~m} / \mathrm{s}$, erodents as shown.

\section{ACKNOWLEDGMENTS}

This work was supported by the U.S. Department of Energy (DOE), Office of Science and Technology, as part of the Mixed Waste Focus Area, and the Argonne Division of Educational Programs with funding from DOE, under Contract W-31-109-Eng-38.

\section{REFERENCES}

1. L. Lamarre, Elect. Pow. Res. Inst. J., 1994, April/May, 22.

2. D. Singh, A. S. Wagh, J. C. Cunnane, and J. L. Mayberry, J. Environ. Sci. Health A32, 527 (1997).

3. D. Singh and A. S. Wagh, Mater. Technol. 12, 149 (1997).

4. A. S. Wagh, S. Y. Jeong, and D. Singh, Ceram. Trans. 87, 63 (1998).

5. D. Singh, V. Mandalika, A. S. Wagh, R. V. Strain, and M. Tlustochowicz, Ceram. Trans. 87, 653 (1998).

6. A. S. Wagh and D. Singh, Radwaste Mag., 1998, January, 46.

7. Closing the Circle on the Splitting of the Atom, U.S. Department of Energy, Office of Environmental Management, Washington, DC, 1995.

8. K. C. Goretta, M. L. Burdt, M. M. Cuber, L. A. Perry, D. Singh, A. S. Wagh, J. L. Routbort, and W. J. Weber, Wear, in press (1999).

9. J. L. Routbort and R. O. Scattergood, Key Eng. Mater. 71, 23 (1992).

10. G. P. Tilly and W. Sage, Wear 16, 447 (1970).

11. A. G. Evans, M. E. Gulden, and M. Rosenblatt, Proc. R. Soc. London Ser. A 361, 343 (1978).

12. A. W. Ruff and S. M. Wiederhorn, in Treatise on Materials Science and Technology, Vol. 16, edited by C. M. Preece (Academic Press, New York, 1979), p. 69.

13. G. Sundararajan, Wear 84, 217 (1983). 
14. C. M. Preece and N. H. MacMillan, Ann. Rev. Mater. Sci. 7, 95 (1977).

15. U.S. Environmental Protection Agency, Method 1311, Toxicity Characteristic Leaching Procedure (TCLP), Rev. II (1992), p. 138.

16. Method ANSI/ANS 16.1, American Nuclear Society, La Grange Park, IL (1986).

17. J. L. Routbort and R. O. Scattergood, J. Am. Ceram. Soc. 63, 595 (1980).

18. K. C. Goretta, J. L. Routbort, A. Mayer, and R. B. Schwarz, J. Mater. Res. 2, 818 (1987).

19. C. S. Yust and R. S. Crouse, Wear 51, 193 (1978).

20. S. Y. Jeong, Ph.D. thesis, Illinois Institute of Technology, 1997.

21. A. V. Levy, Z. R. Shui, and B. Q. Wang, Wear 127, 193 (1988).

22. A. Brandstadter, K. C. Goretta, J. L. Routbort, D. P. Groppi, and K. R. Karasek, Wear 147, 155 (1991).

23. W. Wu, K. C. Goretta, and J. L. Routbort, Mater. Sci. Eng. A151, 85 (1992).

24. See, for example, "Ceramic Source, Vol. 6," Am. Ceram. Soc., Westerville, OH (1991).

25. M. Tlustochowicz, M.S. thesis, Northwestern University, 1998. 